\title{
Articles
}

Central European Review of Economics \& Finance

Vol. 17, No. 1(2017), pp. 33-51, D0I: 10.24136/ceref.2017.002

Tadeusz Dyr ${ }^{1}$, Karolina Ziółkowska²

\section{THE INTELLECTUAL CAPITAL AS THE REGIONS' COMPETITIVENESS FACTOR}

Theories of the regional development show that the intellectual capital is an important factor of the regions competitiveness. The main aim of the article is an evaluation of variation of factors determining the intellectual capital level of Polish regions. The paper has been shown that there is a statistically significant relation between the level of economic development of Polish regions, and factors determining the value of intellectual capital.

JEL Classification Codes: 035, C15.

Keywords: region, intellectual capital, econometric model.

\section{Introduction}

Knowledge, as the strategic resource, nowadays becomes a base of functioning not only individual enterprises, but also entire economies. In the economic terms it is treated both as the economic goods, as well as the main factor of the economic development (Figurska, Wiśniewski, 2009, p. 130). Its wide application leads to building the concept of the knowledge-based economy (GOW), i.e. economy, in which the knowledge is treated as the factor creating the production structure and the economic progress at an advanced stage of social-economic development (Skrzypek, 2008, p. 162). It is distinguished by specific characteristics like singling her out the changeability of closer and wider environment, the need of learning and knowledge, the

\footnotetext{
${ }^{1}$ Associate Professor, Ph.D., K. Pulaski University of Technology and Humanities in Radom, Faculty of Economic and Legal Sciences.

${ }^{2}$ Assistant Professor, Ph.D., University of Social Sciences in Lodz.
} 
need of transformation of the industrial society into the information one, dependence of the ability to survive by organization regarding the access to the information, its efficient processing and adaptation to changes. It is also necessary to look globaly at economy, market, environmental protection and notice the growing roll of immaterial resources, like knowledge, intellectual capital and information (Skrzypek, 2009, p. 40).

The economy based on knowledge concept is of particular importance due to create the regions' competitiveness. Regions with the low level of development are characterized by deficit of people with knowledge and investment abilities. The underdeveloped human capital is strongly is closely associated and dependent on place of residence, while well educated people present greater mobility. Consequently, there is an outflow of well qualified employees from the low competitiveness regions to the high competitiveness regions (Figurska, Wiśniewski, 2009, p. 131). It is crucial factor of the regional divergence. Underdeveloped regions remain the place of the production location, exploiting basic resources. Well-developed regions with increasing speed collecting and creating new knowledge, implement innovations and improve their competitiveness.

With time the knowledge becomes widely available. Keeping the high regions' competitiveness it needed to be further renovating and replacing by new one. Moreover, it entails the need to permanent incur the expenditure, for which it is hard to determine the cost-effectiveness and expected return rate. Not-applied knowledge has no value, and the inappropriate knowledge (outdated or badly applied) can bring losses (Makulska, 2012, p. 179). Regions with the high level of development have a greater investment opportunity into the knowledge and are willing to accept the greater risk of lossmaking investments.

Considering presented premises, as an explicit objective of the article an evaluation of variation of factors determining the intellectual capital level of Polish regions was accepted. To achieve that objective the following research hypotheses were adopted:

H1: Regions in Poland are characterized by high diversity of factors determining the value of intellectual capital.

H2: There is a statistically significant relation between the level of economic development of Polish regions, and factors determining the value of intellectual capital.

For the verification of formulated hypotheses an econometric model with use of the rates informational capacities method (Hellwig method) was constructed (Hellwig, 1968). This method enables constructing the synthetic 
index according to a fragmentary variables diagnostic, reflecting various aspects of analysed facets (Dyr, Ziółkowska, 2014).

\section{Methodological Evaluation of Intelectual Capital}

Next stages of the analysis included:

- creating the preliminary list of diagnostic denominators,

- creating the final set of diagnostic denominators,

- standardization of diagnostic denominators,

- calculating taxonomical indexes.

The preliminary list of diagnostic denominators included all indicators, available in public statistics, referring to various aspects of the regions' intellectual capital in Poland. In creating the final set of diagnostic indicators based on this list, variables - characterized by a relatively high diversity were selected. Variables were determined according to the classical variation coefficient. They assumed that weak diagnostic properties are those denominators, for which the classical variation coefficient based on the standard deviation, is smaller than the threshold value of $10 \%$. As a result of the elimination of unimportant indicators - for which the variation coefficient was smaller than $10 \%$ - a final set of diagnostic indicators was received. It is a base for the further analysis, and a basis for the calculation for every variable of the synthetic index.

The diagnostic variable set of the region's intellectual capital evaluation is described in Table 1. The variables' values were assumed according to data collected under the public statistics and disclosed by the Central Statistical Office. Accepting such a source ensured the comparability of statistical data and their relatively high credibility. A quality system existing in GUS guarantees these statistical denominators.

The necessary condition to set the synthetic index of the regions' competitiveness and their economic infrastructure equipment correctly is their denominators standardization, in which the variables will be comparable and their character standardized - by transforming de-stimulants into stimulants (Grabiński, Wydymus, Zeliaś, 1989, p. 27). 
Table 1. Intellectual Capital Evaluation Indexes

\begin{tabular}{|c|c|c|c|c|}
\hline \multicolumn{2}{|c|}{ Taxonomical Index } & \multicolumn{3}{|c|}{ Diagnostic Variables } \\
\hline Symbol & Name & Symbol & Name & Type \\
\hline \multirow{3}{*}{$x_{1}$} & \multirow{3}{*}{ Learning languages } & $x_{1.1}$ & $\begin{array}{l}\text { Participation of primary school students learning } \\
\text { additional foreign language }[\%]\end{array}$ & stimulant \\
\hline & & $x_{1.2}$ & $\begin{array}{l}\text { Participation of gymnasium students learning } \\
\text { additional foreign language [\%] }\end{array}$ & stimulant \\
\hline & & $x_{1.3}$ & $\begin{array}{l}\text { Participation of high school students learning } \\
\text { additional foreign language [\%] }\end{array}$ & stimulant \\
\hline \multirow{5}{*}{$x_{2}$} & \multirow{5}{*}{$\begin{array}{l}\text { Attractiveness } \\
\text { of education system }\end{array}$} & $x_{2.1}$ & $\begin{array}{l}\text { Graduates of higher education institutions } \\
\text { per } 10,000 \text { inhabitants }\end{array}$ & stimulant \\
\hline & & $x_{2.2}$ & $\begin{array}{l}\text { Participation of students on natural } \\
\text { and technical faculties }\end{array}$ & stimulant \\
\hline & & $x_{2.3}$ & Number of students per 10,000 inhabitants & stimulant \\
\hline & & $\mathrm{X}_{2.4}$ & Number of PhD students per 10,000 inhabitants & stimulant \\
\hline & & $x_{2.5}$ & Participation of foreign students learning in Poland & stimulant \\
\hline \multirow{5}{*}{$x_{3}$} & \multirow{5}{*}{$\begin{array}{l}\text { The } R \& D \& I \\
\text { activities }\end{array}$} & $\mathrm{x}_{3.1}$ & $\begin{array}{l}\text { Intramural expenditures for research } \\
\text { and development per } 1 \text { inhabitant }\end{array}$ & stimulant \\
\hline & & $x_{3.2}$ & $\begin{array}{l}\text { Intramural expenditures for research } \\
\text { and development in relation to GDP [\%] }\end{array}$ & stimulant \\
\hline & & $x_{3.3}$ & $\begin{array}{l}\text { Participation of people employed in R+B activity } \\
\text { in working population [\%] }\end{array}$ & stimulant \\
\hline & & $x_{3.4}$ & $\begin{array}{l}\text { The expenditures of innovation activities } \\
\text { in companies in relation to GDP [\%] }\end{array}$ & stimulant \\
\hline & & $\mathrm{x}_{3.5}$ & $\begin{array}{l}\text { The share of net revenues from sales } \\
\text { of innovation products in total net sales revenue [\%] }\end{array}$ & stimulant \\
\hline
\end{tabular}

Source: Own study.

In the regions' intellectual capital evaluation, the denominators standardization was done by conducting the standardization $j$-th variable in $i$-th region. The calculations were done using following formulas:

for stimulants:

$$
t_{i j}=\frac{x_{i j}-\bar{x}}{S_{j}}
$$

for de-stimulants:

where:

$$
t_{i j}=-\frac{x_{i j}-\bar{x}}{S_{j}}
$$

$t_{i j}$ - standardized value of $j$-th index in $i$-th subdivision, 
$x_{i j}$ - value of $j$-th denominator in $i$-th subdivision,

$\bar{x}$ - the arithmetic mean of $j$ - denominator value,

$S_{j}$ - standard deviation in $x_{j}$ denominator distribution.

Using the final set of diagnostic indicators after the standardization, values of Hellwig taxonomical indexes of development were calculated for each region, i.e. synthetic indexed were calculated for each of distinguished variables and fragmentary indexes - for aspects distinguished under individual areas.

In the Hellwig method, according to the matrix of standardized variables, a model object of following coordinates was set:

$$
0=\left[x_{0 j}\right]
$$

where:

$x_{0 j}=\max _{i}\left\{t_{i j}\right\}$ - for stimulants,

$t_{i j}$ - standardized value of $j$-th index in $i$-th subdivision.

Calculating the synthetic index of the regions competitiveness only the formula for stimulants was used, because amongst the denominators admitted to the evaluation there weren't any de-stimulants.

The next step was to set the Euclidean distance from the model object:

$$
d_{i 0}=\sqrt{\sum_{j=1}^{m}\left(t_{i j}-x_{0 j}\right)^{2}}
$$

where:

$d_{i 0}$ - Euclidean distance between $i$-th and the model object,

$t_{i j}$ - standardized value of $j$-th index in $i$-th subdivision,

$i=1,2, \ldots, n$,

$j=1,2, \ldots, m$,

Considering presented assumptions it is possible to calculate the synthetic index from the following formula:

where:

$$
S_{i}=1-\frac{d_{i 0}}{d_{0}}
$$

$d_{i 0}$ - Euclidean distance between $i$-th and the model object,

$d_{0}$ - the unit critical distance from the model:

$$
d_{0}=\bar{d}_{i 0}+2 \cdot S_{0}
$$

$\bar{d}_{i 0}$ - arithmetic mean of taxonomical distances between the object $i$-th and the model object: 


$$
\bar{d}_{0}=\frac{1}{n} \cdot \sum_{i=1}^{n} d_{i 0}
$$

$S_{0}$ - standard deviation of taxonomical distances between $i$-th and the model object:

$$
S_{0}=\sqrt{\frac{1}{n} \cdot \sum_{i=1}^{n}\left(d_{i 0}-\bar{d}_{0}\right)^{2}}
$$

In the above model, the synthetic index of the regions competitiveness and their equipping with the economic infrastructure the Si assumes values from the period $[0 ; 1]$. Maximum value of the $S_{i}$ index (1) reflects the so-called model, i.e. the region, in which all analysed variables accept the maximum values. In the adopted method, along with increasing the value of the synthetic index, both the region's competitiveness or a level of equipping it with the infrastructure also increase. Differences between indexes show a distance in the development of individual regions.

Using the three averages method a classification of regions according to value of competitiveness synthetic index was presented. This method enables the division of regions into 4 groups. In this procedure:

- regions were arranged according to decreasing value of the competitiveness measures,

- the arithmetic average $m$ of value of the competitiveness measures was calculated,

- for regions, for which competitiveness measures were greater than the calculated average $m$, the $m_{1}$ average was calculated,

- for regions, for which competitiveness measures were lower than the calculated average $m$, the $m_{2}$ average was calculated.

Calculated values of $m, m_{1}$ and $m_{2}$ made it possible to divide the regions into 4 groups:

- group I- regions with the high level of competitiveness, for which the synthetic index is $S_{i} \geq m_{1}$,

- group II - regions with the middle level of competitiveness, for which the synthetic index is between: $m \leq S_{i}<m_{1}$,

- group III - regions with the low level of competitiveness, for which the synthetic index is between: $m_{2}<S_{i}<m$,

- group IV - regions with the very low level of competitiveness, for which the synthetic index is between $S_{i} \leq m_{2}$. 


\section{Learning foreign languages}

Linguistic abilities in times of economy globalisation gain become increasingly important, because they are contributing factor of the occupational mobility, the international movement of people and capital of the access to knowledge. An education of foreign languages at school where children and teenagers are acquiring basic language skills is particularly important. The current educational system assumes teaching one foreign language at primary schools and two foreign languages at secondary schools. Assessing spatial diversity of the amount of intellectual and social capital in the linguistic competence area, diagnostic variables presenting the participation of primary school, secondary school and post-secondary school pupils who learn foreign language as additional one (apart from the school duty) were accepted. These values were calculated as the average from years 2011-2015. Accepting the average value allows for eliminating short-term hesitations of teaching, not-reflecting real trends. Value of diagnostic variables and algorithm of calculating the synthetic taxonomical index reflecting the region's competitiveness in studied area was presented in table 2.

On each teaching level there is a wide diversity of participation of children and teenagers who undertake learning additional foreign language. On the primary school level greater participation of children learning additional foreign language is in Opole region. At subsequent education levels in this region participation of young people learning additional language is the lowest.

Gymnasium pupils most willingly learn additional foreign language. However, since September $1^{\text {st }}, 2009$ after the introduction of the mandatory second foreign language at gymnasiums (DzU 2009, $\mathrm{nr} 4$, poz. 17) this participation was reduced considerably, although it is still much higher than at primary and secondary schools. In 2015 almost 15\% gymnasium pupils were learning additional foreign language. At primary schools this percentage amounted $7.8 \%$ and at secondary schools $5 \%$. 
Table 2. Calculating the Taxonomical Index of Learning Foreign Language $\left(x_{1}\right)$, as the factor determining the value of intellectual capital

\begin{tabular}{|l|r|c|c|c|c|c|c|c||}
\hline \multirow{2}{*}{ Region } & \multicolumn{3}{|c|}{ Variable Value } & \multicolumn{2}{c|}{ Standardized Variable Value } & \multicolumn{2}{c|}{$\begin{array}{c}\text { Euclidean } \\
\text { Distance }\end{array}$} & $\begin{array}{c}\text { Synthetic } \\
\text { Index }\end{array}$ \\
\cline { 2 - 11 } & $\mathrm{x}_{1.1}$ & $\mathrm{x}_{1.2}$ & $\mathrm{x}_{1.3}$ & $\mathrm{t}_{1.1}$ & $\mathrm{t}_{1.2}$ & $\mathrm{t}_{1.3}$ & $\mathrm{~d}_{1.0}$ & $\mathrm{~S}_{1}$ \\
\hline Dolnośląski & 13.94 & 18.55 & 4.94 & 1.25 & 0.56 & -0.16 & 1.93 & $\mathbf{0 . 6 2}$ \\
\hline Kujawsko-Pomorski & 9.22 & 18.12 & 2.37 & -0.47 & 0.41 & -1.65 & 3.80 & $\mathbf{0 . 2 4}$ \\
\hline Lubelski & 12.44 & 15.59 & 6.36 & 0.70 & -0.48 & 0.67 & 2.22 & $\mathbf{0 . 5 6}$ \\
\hline Lubuski & 12.22 & 17.03 & 4.64 & 0.62 & 0.02 & -0.34 & 2.47 & $\mathbf{0 . 5 1}$ \\
\hline Łódzki & 10.47 & 21.14 & 6.80 & -0.02 & 1.47 & 0.92 & 1.46 & $\mathbf{0 . 7 1}$ \\
\hline Małopolski & 6.80 & 16.63 & 5.64 & -1.36 & -0.12 & 0.24 & 3.36 & $\mathbf{0 . 3 3}$ \\
\hline Mazowiecki & 11.23 & 20.61 & 7.44 & 0.26 & 1.28 & 1.29 & 1.09 & $\mathbf{0 . 7 8}$ \\
\hline Opolski & 14.09 & 10.19 & 2.60 & 1.31 & -2.38 & -1.51 & 4.92 & $\mathbf{0 . 0 2}$ \\
\hline Podkarpacki & 9.49 & 16.64 & 7.88 & -0.37 & -0.11 & 1.54 & 2.31 & $\mathbf{0 . 5 4}$ \\
\hline Podlaski & 11.48 & 16.35 & 6.73 & 0.35 & -0.22 & 0.88 & 2.05 & $\mathbf{0 . 5 9}$ \\
\hline Pomorski & 10.19 & 12.72 & 4.00 & -0.12 & -1.49 & -0.70 & 3.98 & $\mathbf{0 . 2 1}$ \\
\hline Śląski & 5.59 & 14.66 & 5.87 & -1.80 & -0.81 & 0.38 & 4.03 & $\mathbf{0 . 2 0}$ \\
\hline Świętokrzyski & 9.56 & 18.59 & 6.43 & -0.35 & 0.57 & 0.70 & 2.06 & $\mathbf{0 . 5 9}$ \\
\hline Warmińsko-Mazurski & 5.49 & 15.97 & 4.65 & -1.83 & -0.35 & -0.33 & 4.09 & $\mathbf{0 . 1 9}$ \\
\hline Wielkopolski & 12.49 & 19.68 & 4.50 & 0.72 & 0.96 & -0.42 & 2.11 & $\mathbf{0 . 5 8}$ \\
\hline Zachodniopomorski & 13.48 & 18.92 & 2.59 & 1.08 & 0.69 & -1.52 & 3.17 & $\mathbf{0 . 3 7}$ \\
\hline Arithmetic Mean & 10.51 & 16.96 & 5.21 & 0.00 & 0.00 & 0.00 & 2.82 & $\mathbf{0 . 4 4}$ \\
\hline Standard Deviation & 2.74 & 2.84 & 1.73 & 1.00 & 1.00 & 1.00 & 1.10 & $\mathbf{0 . 2 2}$ \\
\hline Variation Coefficient & $26 \%$ & $17 \%$ & $33 \%$ & - & - & - & $39 \%$ & $\mathbf{5 0 \%}$ \\
\hline Max & 14.09 & 21.14 & 7.88 & 1.31 & 1.47 & 1.54 & 4.92 & $\mathbf{0 . 7 8}$ \\
\hline Min & 5.49 & 10.19 & 2.37 & -1.83 & -2.38 & -1.65 & 1.09 & $\mathbf{0 . 0 2}$ \\
\hline \hline
\end{tabular}

Source: Own study, based on GUS data.

To the group of regions with the highest synthetic index of competitiveness according to the criterion of learning foreign languages are Mazovian, Łódź and Lower Silesia provinces (fig. 1). In Mazovian and Łódź regions participation of children and teenagers learning additional foreign language is on each level higher than the average in Poland. In the Lower Silesia region the high value of the synthetic index was obtained thanks to the greater participation of children and teenagers learning additional language at primary schools and gymnasiums. At secondary schools this participation is a little bit lower than the average in Poland. 


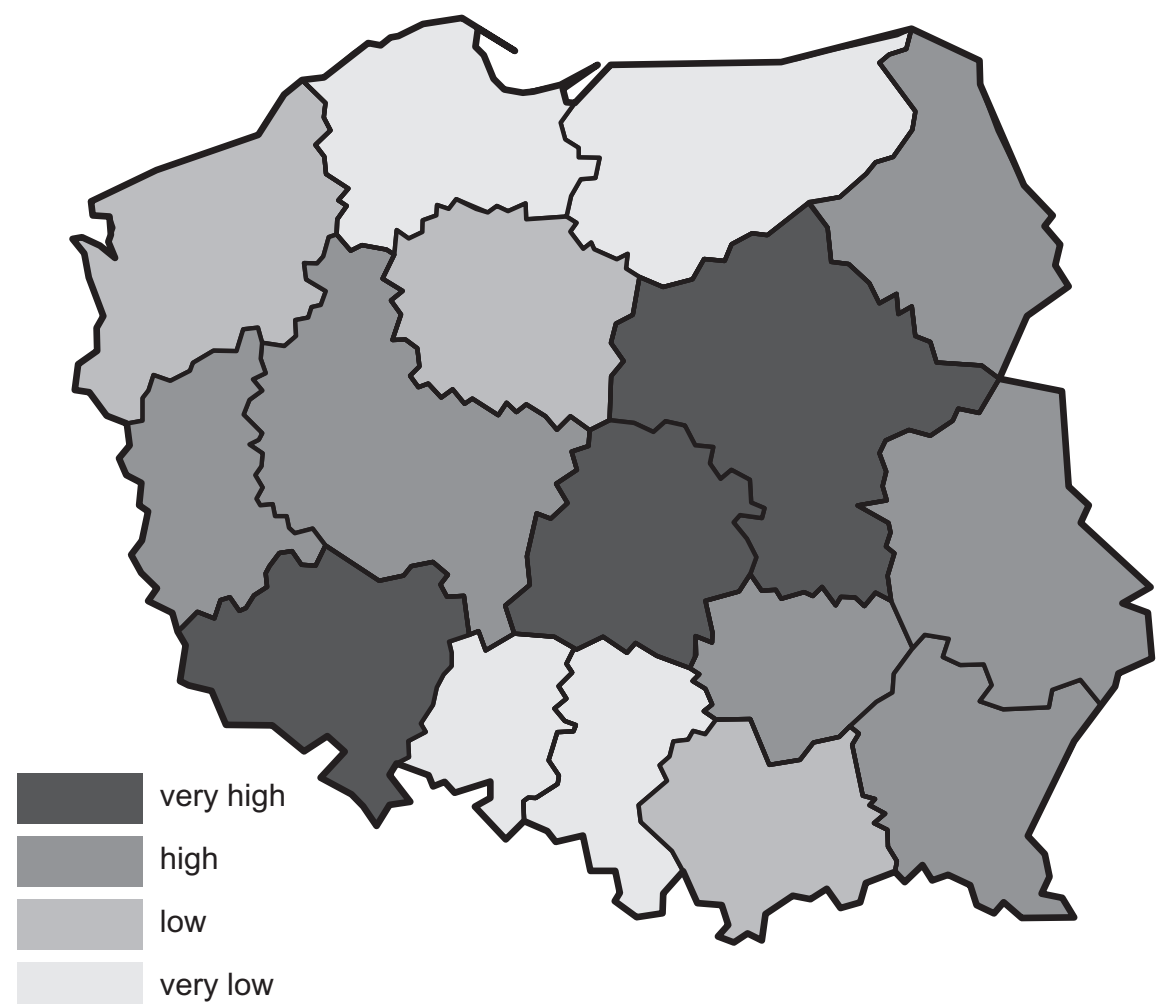

Figure 1. Spatial diversity of Taxonomical Index of Learning Foreign Language $\left(x_{1}\right)$, as the factor determining the value of intellectual capital

Source: Own study.

The lowest synthetic index value was in Opole region. In the region, as mentioned above, there is the highest participation of children learning additional foreign language at primary schools. In gymnasiums this participation is twice lower than the average in Poland, and in secondary schools even triple lower. As a consequence the synthetic index amounts only 0,02 and locates the Opole region close to the anti-model of competitiveness.

\section{Attractiveness of education system}

In creating the intellectual capital, being a factor of regions' competitiveness, a level of education and participation in educational processes is very important. Skills upgrading is has a primary importance for economy growth and improvement of EU competitiveness, as well as creating new, attractive 
workplaces, ability to adapt to changes and reduce developmental disproportions. (COM(2008) 868). Value of diagnostic variables and algorithm of calculating the synthetic taxonomical index reflecting the region's attractiveness of education system in studied area was presented in table 3.

Table 3. Calculating the Taxonomical Index of Attractiveness of education system $\left(x_{2}\right)$, as the factor determining the value of intellectual capital

\begin{tabular}{|c|c|c|c|c|c|c|c|c|c|c|c|c|}
\hline \multirow{2}{*}{ Region } & \multicolumn{5}{|c|}{ Variable Value } & \multicolumn{5}{|c|}{ Standardized Variable Value } & \multirow{2}{*}{ 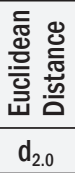 } & \multirow{2}{*}{ 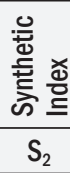 } \\
\hline & $\mathrm{X}_{2.1}$ & $\mathrm{X}_{2.2}$ & $\mathrm{X}_{2.3}$ & $\mathrm{x}_{2.4}$ & $\mathrm{X}_{2.5}$ & $t_{2.1}$ & $t_{2.2}$ & $t_{2.3}$ & $t_{2.4}$ & $t_{2.5}$ & & \\
\hline Dolnośląski & 145.60 & 69.17 & 1.02 & 7.14 & 122.1 & 0.21 & 1.05 & 1.05 & 0.68 & -3.75 & 5.35 & 0.31 \\
\hline Kujawsko-Pomorski & 116.09 & 59.64 & 1.79 & 8.02 & 15.1 & -0.17 & 0.10 & -0.37 & 0.00 & 0.24 & 4.88 & 0.37 \\
\hline Lubelski & 85.17 & 46.18 & 2.01 & 8.64 & 14.7 & -0.58 & -1.25 & -0.78 & -0.48 & 0.26 & 6.12 & 0.21 \\
\hline Lubuski & 72.78 & 64.96 & 1.62 & 8.51 & 15.1 & -0.74 & 0.63 & -0.06 & -0.38 & 0.24 & 5.18 & 0.33 \\
\hline Łódzki & 136.87 & 63.08 & 1.11 & 6.11 & 14.0 & 0.10 & 0.44 & 0.88 & 1.47 & 0.28 & 3.58 & 0.54 \\
\hline Małopolski & 222.13 & 48.48 & 1.60 & 7.54 & 15.7 & 1.22 & -1.02 & -0.04 & 0.37 & 0.22 & 4.34 & 0.44 \\
\hline Mazowiecki & 150.43 & 64.28 & & 5.24 & 15.7 & 0.28 & & 1.87 & & 0.22 & 3.17 & 0.59 \\
\hline Opolski & 105.82 & 51.92 & 1.54 & 9.12 & 13.1 & -0.31 & -0.67 & 0.09 & -0.84 & 0.31 & 5.52 & 0.29 \\
\hline Podkarpacki & 119.22 & 41.25 & 2.46 & 10.03 & 15.2 & -0.13 & -1.74 & -1.62 & -1.54 & 0.24 & 7.04 & 0.09 \\
\hline Podlaski & 58.89 & 60.56 & 2.25 & 9.57 & 14.3 & -0.92 & 0.19 & -1.23 & -1.19 & 0.27 & 6.34 & 0.18 \\
\hline Pomorski & 126.03 & 64.42 & 1.24 & 7.24 & 16.3 & -0.04 & 0.58 & 0.63 & 0.60 & 0.20 & 3.98 & 0.49 \\
\hline Śląski & 370.62 & 77.13 & 0.83 & 7.23 & 14.1 & 3.17 & 1.85 & 1.40 & 0.61 & 0.28 & 1.59 & 0.79 \\
\hline Świętokrzyski & 107.35 & 44.64 & 2.04 & 8.59 & 13.8 & -0.29 & -1.40 & -0.84 & -0.44 & 0.29 & 6.04 & 0.22 \\
\hline Warmińsko-Mazurski & 59.56 & 59.07 & 2.19 & 9.67 & 15.4 & -0.91 & 0.04 & -1.12 & -1.27 & 0.23 & 6.36 & 0.18 \\
\hline Wielkopolski & 116.52 & 54.87 & 1.31 & 7.36 & 16.1 & -0.17 & -0.38 & 0.50 & 0.51 & 0.21 & 4.54 & 0.41 \\
\hline Zachodniopomorski & 74.72 & 68.56 & 1.78 & 8.30 & 14.4 & -0.72 & 0.99 & -0.36 & -0.22 & 0.27 & 5.13 & 0.34 \\
\hline Arithmetic Mean & 129.24 & 58.64 & 1.58 & 8.02 & 21.57 & 0.00 & 0.00 & 0.00 & 0.00 & 0.00 & 4.95 & 0.36 \\
\hline Standard Deviation & 76.18 & 9.99 & 0.54 & 1.30 & 26.82 & 1.00 & 1.00 & 1.00 & 1.00 & 1.00 & 1.40 & 0.18 \\
\hline Variation Coefficient & $59 \%$ & $17 \%$ & $34 \%$ & $16 \%$ & $124 \%$ & - & - & - & - & - & $28 \%$ & $50 \%$ \\
\hline Max & 370.6 & 77.1 & 2.5 & 10.0 & 122.1 & 3.17 & 1.85 & 1.87 & 2.13 & 0.31 & 7.04 & 0.79 \\
\hline Min & 145.6 & 69.2 & 1.0 & 7.1 & 122.1 & 0.21 & 1.05 & 1.05 & 0.68 & -3.75 & 5.35 & 0.31 \\
\hline
\end{tabular}

Source: Own study, based on GUS data.

The crucial factors of attraction of educational system evaluation are measures reflecting the schooling rate and results from gymnasium examination and possibility of maturity examinations. Their spatial diversity level is very low. In this situation one concentrated on the indicators concerning the participation in educational processes at higher education level. Identified diagnostic variables were accepted, as average values from years 2010-2015. 
In 2015 in Poland there were 103 graduates per 10000 inhabitants. In recent years this number has been systematically diminishing. In relation to the maximum value it reduced by $20 \%$. This fall is undeniable related to negative demographic trends. The declining number of young people causes, that less and less people undertake higher education. It is reflected in the number of students. The ratio of students per 10000 inhabitants has dropped from 472 in 2010 to 365 in 2015, i.e. by 28\%. The biggest decrease is observed in the Świętokrzyski region (40\%), and the smallest in Pomeranian (12.1\%).

Poles more and more willingly undertake PhD studies. The number of participants of these studies has been systematically increasing. The rate of the number of doctoral students per 10000 inhabitants has increased from 9.5 in 2010 to 11.2 in 2015, i.e. by $17.7 \%$. The most doctoral students per 10000 inhabitants were in 2015 in the Mazovian region (20.3), the least in Podkarpacki region (2.7). The positive trend in the higher education is also a rise of students on technical and natural faculties. It has increased from $23.1 \%$ in 2010 to $29.8 \%$ in 2015 , i.e. about $6.7 \%$.

Polish colleges more and more willingly are chosen by foreigners. Their participation in the total number of students has increased from $1.2 \%$ in 2010 to $4 \%$ in 2015, i.e. about $2.8 \%$. Relatively many foreigners study in colleges in regions of Eastern Poland. These colleges actively acquire students from Eastern Europe, for whom undertaking studies in Poland is a chance to receive a diploma in one of the European Union member states.

Based on identified diagnostic variables of attractiveness of education system, the competitiveness' synthetic indexes were calculated. Their spatial diversity was described graphically in figure 2 .

Regions competitiveness' synthetic index calculated based on variables characterized the attractiveness of educational system, achieved values from 0.04 to 0.70 , in which for most regions didn't cross 0.6.

The highest value of regions competitiveness' synthetic index calculated based on variables characterized the attractiveness of educational system, achieved Małopolska region $(0,70)$. Lower values of the index had Low Silesian $(0,64)$ and Mazowieckie $(0,62)$ regions. In these regions definitely higher are indicators of the number of graduates, students and doctoral students per 10000 inhabitants. Moreover in Małopolska and Lower Silesia regions the participation of students on technical and natural faculties is about $4 \%$ higher than in the next region (Pomeranian -28.87\%). 


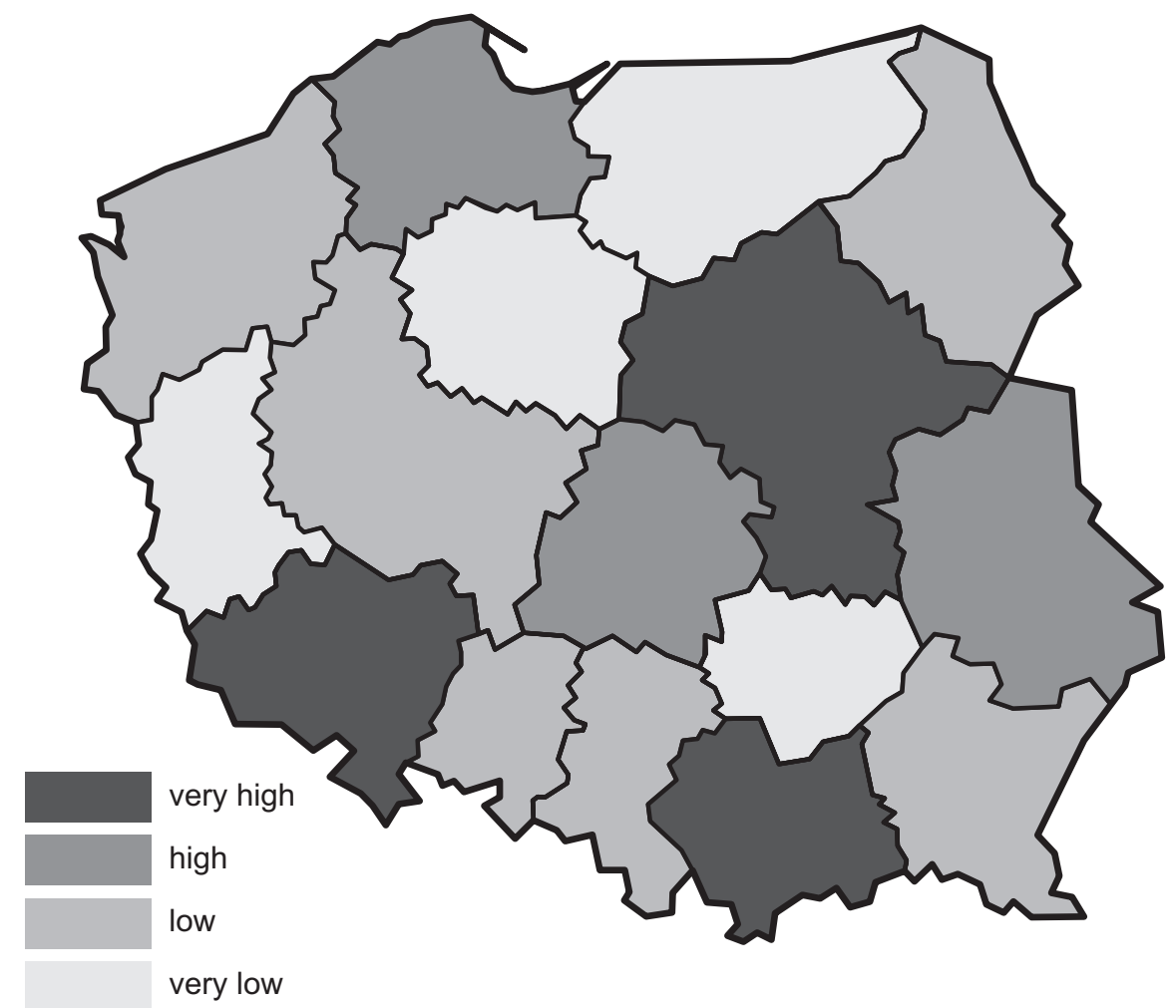

Figure 2. Spatial diversity of Taxonomical Index of Attractiveness of education system $\left(\mathrm{x}_{2}\right)$, as the factor determining the value of intellectual capital

Source: Own study.

The high level of competitiveness according to the criterion of attractiveness of educational system got the Lublin region. This region is a determined leader in the education of foreigners. In terms of the number of graduates, students and doctoral students indicator is second only to three regions about the highest level of the taxonomical measure according to this criterion.

\section{The R \& D \& I activities}

$B+R$ activity includes systematically conducted creative works, taken in order to increase the stock of knowledge and its application. Seen from this angle this activity is an important factor of region's innovation, influencing its competitiveness. 
Region's innovatio, identified usually with the economy innovation (Skonieczny, Świda, 2008, p. 602-609), a derivative of business entities' innovations, research sector, human and social capital, innovative policy (Feltynowski, Nowakowska, 2009, p. 11-12). It reflects the ability of the region to implement changes, reforms, novel solutions in different fields of the socialeconomic life and the possibility to improve mechanisms of its development (Chądzyński, Nowakowska, Przygodzki, 2007, p. 144). From such a perspective this concept refers to the innovation of J. Schumpetera (Schumpeter, 1960), in which the innovation is identified with the practical application of new solutions, generating economic positive effects (Niedzielski, Rychlik, 2006, s. 19; Niedzielski, 2013, p. 18-26). Value of diagnostic variables and algorithm of calculating the synthetic taxonomical index reflecting the region's $\mathrm{R}+\mathrm{D}+\mathrm{I}$ activity in studied area was presented in table 4 .

Table 4. Calculating the Taxonomical Index of $R+D+I$ activity $\left(x_{3}\right)$, as the factor determining the value of intellectual capital

\begin{tabular}{|c|c|c|c|c|c|c|c|c|c|c|c|c|}
\hline \multirow{2}{*}{ Region } & \multicolumn{5}{|c|}{ Variable Value } & \multicolumn{5}{|c|}{ Standardized Variable Value } & \multirow{2}{*}{ 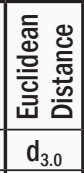 } & \multirow{2}{*}{ 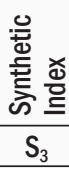 } \\
\hline & $\mathrm{X}_{3.1}$ & $\mathrm{X}_{3.2}$ & $\mathrm{X}_{3.3}$ & $x_{3.4}$ & $x_{3.5}$ & $t_{3.1}$ & $\mathrm{t}_{3.2}$ & $t_{3.3}$ & $t_{3.4}$ & $t_{3.5}$ & & \\
\hline Dolnośląski & 441.2 & 0.74 & 0.99 & 2.49 & 14.97 & 0.29 & 0.04 & 0.65 & 0.78 & 1.48 & 3.99 & 0.52 \\
\hline Kujawsko-Pomorski & 174.6 & 0.34 & 0.54 & 1.66 & 10.57 & -0.61 & -0.82 & -0.57 & -0.06 & 0.50 & 5.99 & 0.28 \\
\hline Lubelski & 342.4 & 1.03 & 0.67 & 0.96 & 5.57 & -0.04 & 0.67 & -0.22 & -0.78 & -0.62 & 5.65 & 0.32 \\
\hline Lubuski & 87.7 & 0.18 & 0.26 & 0.74 & 4.65 & -0.91 & -1.17 & -1.33 & -1.00 & -0.83 & 7.44 & 0.11 \\
\hline Łódzki & 294.0 & 0.67 & 0.65 & 3.27 & 7.71 & -0.21 & -0.11 & -0.27 & 1.57 & -0.14 & 5.22 & 0.38 \\
\hline Małopolski & 628.5 & 1.38 & 1.45 & 1.58 & 9.45 & 0.92 & 1.43 & 1.91 & -0.14 & 0.25 & 3.63 & 0.57 \\
\hline Mazowiecki & 1300.6 & 1.70 & 1.47 & 3.28 & 5.01 & 3.19 & 2.12 & 1.96 & 1.59 & -0.75 & 2.99 & 0.64 \\
\hline Opolski & 121.3 & 0.34 & 0.42 & 0.74 & 5.28 & -0.79 & -0.82 & -0.90 & -1.00 & -0.69 & 6.99 & 0.16 \\
\hline Podkarpacki & 427.2 & 1.38 & 0.88 & 3.44 & 8.32 & 0.24 & 1.43 & 0.36 & 1.75 & -0.01 & 4.10 & 0.51 \\
\hline Podlaski & 252.6 & 0.60 & 0.58 & 0.70 & 4.27 & -0.35 & -0.26 & -0.46 & -1.04 & -0.91 & 6.46 & 0.23 \\
\hline Pomorski & 501.6 & 1.05 & 0.88 & 1.96 & 18.34 & 0.49 & 0.72 & 0.36 & 0.24 & 2.24 & 3.76 & 0.55 \\
\hline Śląski & 295.4 & 0.57 & 0.75 & 1.97 & 10.93 & -0.20 & -0.32 & 0.00 & 0.25 & 0.58 & 5.13 & 0.38 \\
\hline Świętokrzyski & 207.1 & 0.34 & 0.25 & 0.60 & 4.32 & -0.50 & -0.82 & -1.36 & -1.14 & -0.90 & 7.18 & 0.14 \\
\hline Warmińsko-Mazurski & 107.0 & 0.27 & 0.43 & 0.67 & 3.60 & -0.84 & -0.97 & -0.87 & -1.07 & -1.06 & 7.26 & 0.13 \\
\hline Wielkopolski & 378.6 & 0.64 & 1.11 & 1.89 & 14.62 & 0.08 & -0.17 & 0.98 & 0.17 & 1.40 & 4.37 & 0.48 \\
\hline Zachodniopomorski & 129.8 & 0.28 & 0.66 & 1.61 & 5.98 & -0.76 & -0.95 & -0.24 & -0.11 & -0.53 & 6.41 & 0.23 \\
\hline Arithmetic Mean & 355.6 & 0.72 & 0.75 & 1.72 & 8.35 & 0.00 & 0.00 & 0.00 & 0.00 & 0.00 & 5.41 & 0.35 \\
\hline Standard Deviation & 296.0 & 0.46 & 0.37 & 0.98 & 4.47 & 1.00 & 1.00 & 1.00 & 1.00 & 1.00 & 1.47 & 0.18 \\
\hline Variation Coefficient & $83 \%$ & $64 \%$ & $49 \%$ & $57 \%$ & $53 \%$ & - & - & - & - & - & $27 \%$ & $50 \%$ \\
\hline Max & 1300.6 & 1.70 & 1.47 & 3.44 & 18.34 & 3.19 & 2.12 & 1.96 & 1.75 & 2.24 & 7.44 & 0.64 \\
\hline Min & 87.7 & 0.18 & 0.25 & 0.60 & 3.60 & -0.91 & -1.17 & -1.36 & -1.14 & -1.06 & 2.99 & 0.11 \\
\hline
\end{tabular}

Source: Own study, based on GUS data. 
The internal expenditure on $B+R$ includes the expenditure incurred in reporting year for $\mathrm{B}+\mathrm{R}$ works performed in the reporting unit, irrespectively of the source of resources. They constitute the amount of running expenses and investments on fixed assets associated with $B+R$ activity. Values of this expenditure were referred to 1 resident of the region and the region's GDP in current prices. This last indicator is presented with the annual delay (accessible latest data are from 2014).

In 2015 the average capital costs of $B+R$ per 1 resident amounted 469.7 PLN. In the Mazovian region the amount of the B+R expenditure per 1 resident was almost three times higher than the average in Poland and twice higher than in second Małopolska region.

The the average capital costs of $B+R$ per 1 resident increased from 270.4 PLN in 2010 to 469.7 PLN in 2015, i.e. by $74 \%$. A Warmian-Mazurian region was the only region, in which the value capital costs decreased. In this region the expenditure per 1 resident dropped from 119.5 PLN in 2010 to 107.0 PLN in 2015 , i.e. by $10 \%$ (the largest expenditures in this region were carried in 2012 - 146.1 PLN/ 1 resident).

Together with the increase of expenditure level for $B+R$ goes increase of their participation GDP. However this share is still low. In 2014 it amounted on average to $0.94 \%$. The maximum value of this indicator was presented in Mazovian (1.70\%), Lesser Poland (1.38\%) and Podkarpacki (1.38\%) regions.

In 2015 average share of employed in B+R activity among the professionally active population amounted $0.90 \%$. In 2010-2015 it increased of about $0.14 \%$. An increase in employment was recorded in 15 regions. Only in Łódź region, in spite of an increase in expenditure and employment, participation of employed in $\mathrm{B}+\mathrm{R}$ sector slightly decreased (increase in the number of people professionally active was higher than employments in the $B+R$ sector).

The participation of expenses for innovative activity in the relation to GDP is characterized by the highest level of the diversity. Trends of changes of these expenses in the time have various directions. In some years there is an increase, in other slight decline. The average share is on $2.2 \%$ level, but differences in next years don't exceed $0.2 \%$. Podkarpacki region, in which into the participation of the expenditure on the innovative activity in the relation to GDP increased from $1.82 \%$ in 2010 up to $3.44 \%$ in 2015 i.e. $1.62 \%$ is an exception. In 2015 this region reached the highest level of participation of the expenditure on the innovative activity in relation to GDP.

Changes in the expenditure on the innovative activity are reflected in the sale of innovative products. In 2015 average participation of net income from sales of innovative products in total net sales in 2010-2015 amounted 
9.4\%. The highest share was noted in the Pomeranian region (29.2\%). It was over three times higher than Polish average and over twice higher than in second in terms of this measure Greater Poland region.

Based on identified diagnostic variables of $R+D+I$ activity, the competitiveness' synthetic indexes were calculated. Their spatial diversity was described graphically in picture 3 .

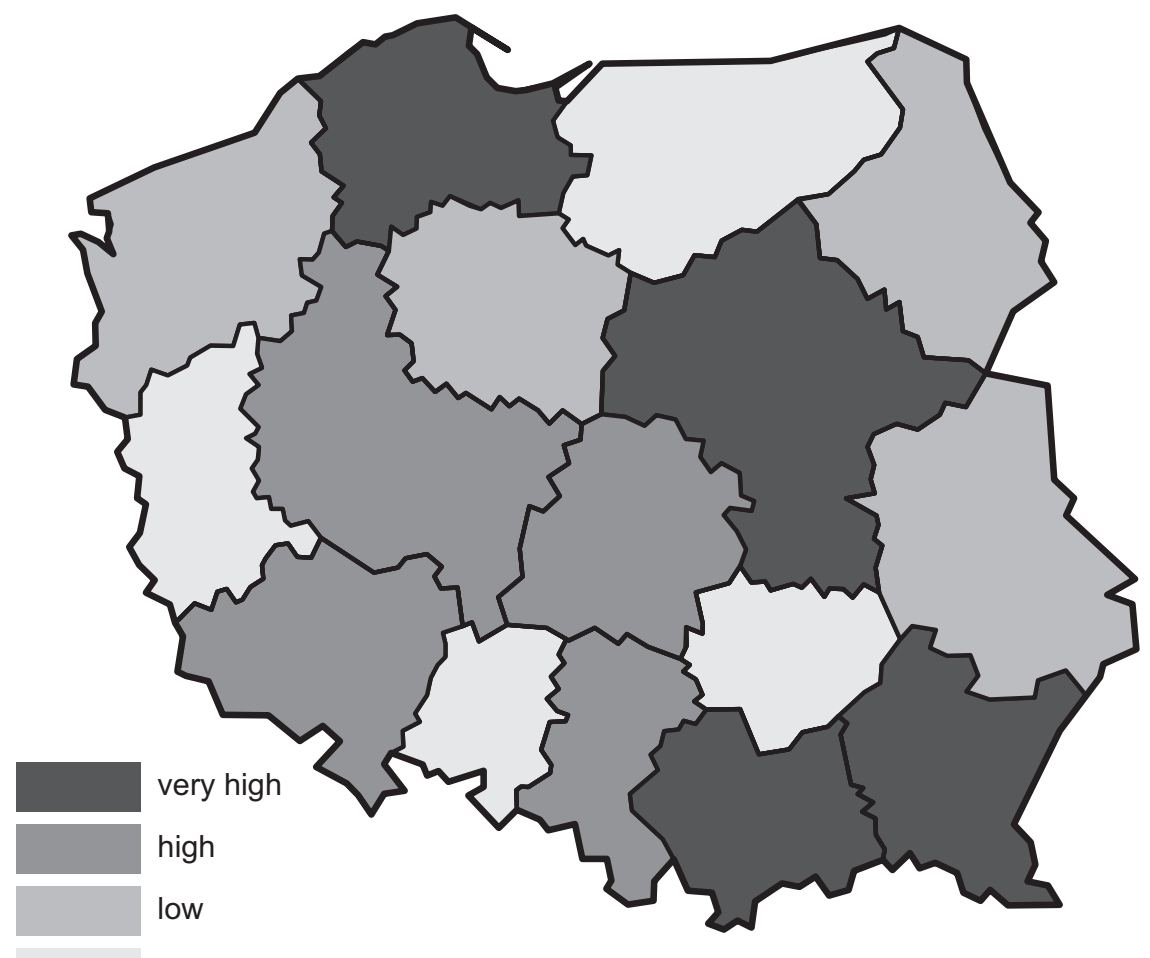

very low

Figure 3. Spatial Spatial diversity of Taxonomical Index of $R+D+I$ activity $\left(x_{3}\right)$, as the factor determining the value of intellectual capital

Source: Own study.

Synthetic taxonomical indexes of competitiveness, calculated based on variables which characterise research-developmental and innovative activity, indicate average diversity of competitiveness level. A Pomeranian region achieved the maximum value of this index (0.57), whereas Lubuskie region the lowest (0.10). Relatively high is the distance from the model, as well as the anti-model of the competitiveness. Such a forming of synthetic indexes 
results from considerable diversity of diagnostic variables and achieving maximum values of individual variables by various regions.

\section{Conclusions}

According to analysed set of diagnostic indicators for every region a synthetic index of competitiveness according to the criterion of the intellectual capital was calculated. Spatial diversity of the regions' competitiveness according to the criterion of the intellectual capital was described in table 5. In the graphical form they were presented in picture 4 .

Calculations' results presented in table 5 show that there is a high level of spatial diversity of factors determining the intellectual capital. So that they prove the first research hypothesis.

In order to prove the second research hypothesis a coefficient of correlation between the value of the intellectual capital and the level of the economic development of regions measured with the GDP value per capita in 2005-2015 was calculated. The value of this rate amounts 0.68 . It confirms that there is a statistically significant relation between these variations. The highest impact on this relation have factors associated with regions' B\&R activity by determining creation of the based on knowledge economy.

Table 5. The synthetic index regions' competitiveness according to the criterion of the Intellectual capital in 2015

\begin{tabular}{|c|c|c|c|}
\hline Region & Competitiveness index & Place in the ranking & Level of Competitiveness \\
\hline Mazowiecki & 0.57 & 1 & \multirow{3}{*}{ Very high } \\
\hline Małopolski & 0.50 & 2 & \\
\hline Dolnośląski & 0.50 & 3 & \\
\hline Pomorski & 0.37 & 4 & \multirow{5}{*}{ High } \\
\hline Łódzki & 0.34 & 5 & \\
\hline Lubelski & 0.34 & 6 & \\
\hline Wielkopolski & 0.32 & 7 & \\
\hline Śląski & 0.31 & 8 & \\
\hline Podkarpacki & 0.29 & 9 & \multirow{4}{*}{ Low } \\
\hline Podlaski & 0.26 & 10 & \\
\hline Zachodniopomorski & 0.23 & 11 & \\
\hline Opolski & 0.20 & 12 & \\
\hline Kujawsko-Pomorski & 0.15 & 13 & \multirow{4}{*}{ Very low } \\
\hline Świętokrzyski & 0.15 & 14 & \\
\hline Lubuski & 0.11 & 15 & \\
\hline Warmińsko-Mazurski & 0.04 & 16 & \\
\hline
\end{tabular}

Source: Own study. 


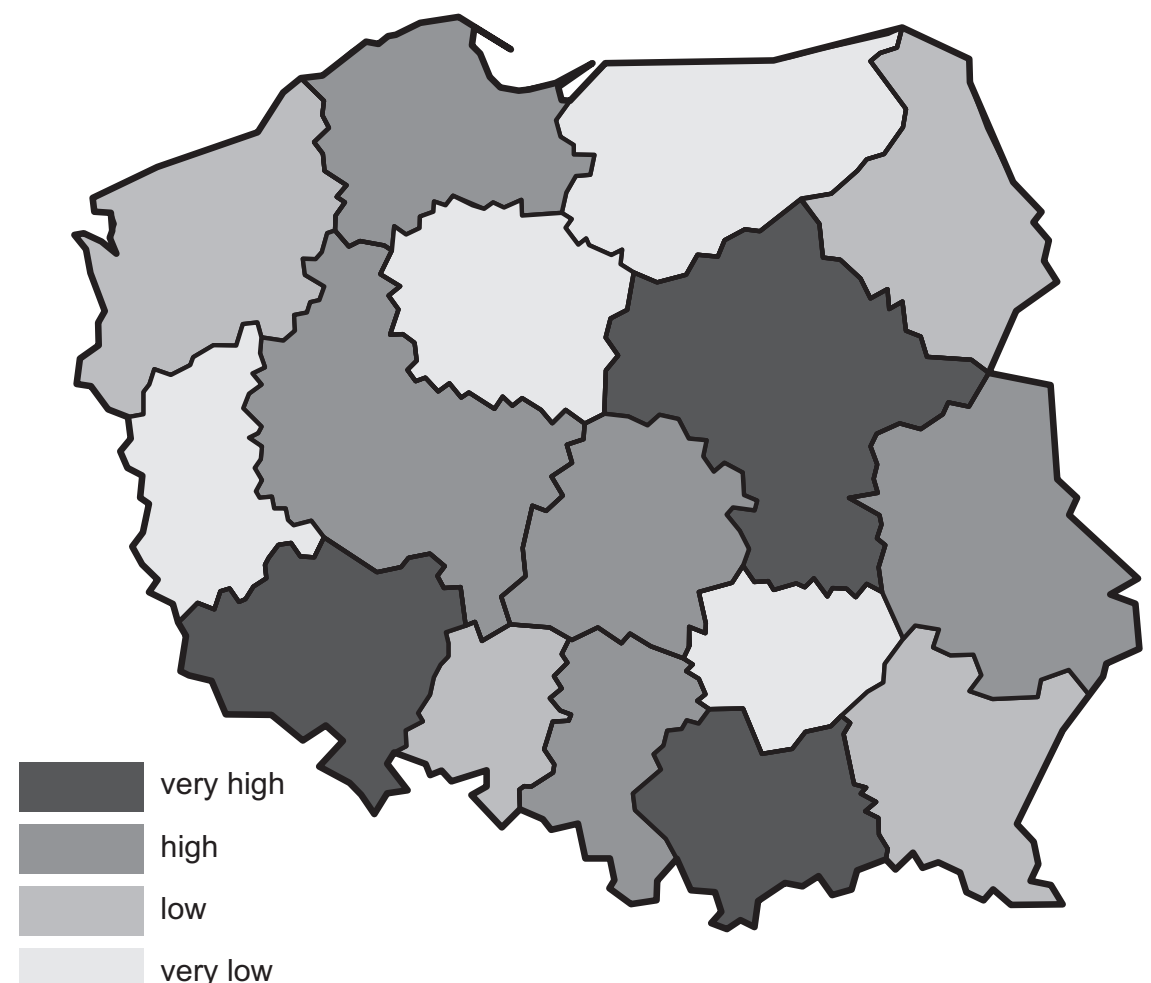

Figure 4. Spatial diversity of the regions' competitiveness according to the criterion of the intellectual capital

Source: Own study.

The relation between the learning of foreign languages and the level of economic development is relatively on the low level. Command of foreign languages, being more and more common, is essential, though insufficient for creating the regions' a competitive advantage.

The main problems include relatively low share of the expenditure on the research and development and innovative activity, low employment in research-developmental and innovative activity companies. Also a participation in sales of innovative products is small. In the economy based on the knowledge the minimum value of the intellectual capital can be an essential barrier of the economic development and negatively influence the competitiveness of Polish regions. 


\section{References:}

Chądzyński J., Nowakowska A. (2007). Przygodzki Z., Region i jego rozwój w warunkach globalizacji, Wydawnictwo CedeWu, Warszawa.

$\operatorname{COM}(2008)$ 868: Communication from the Commission to the European Parliament, the Council, the European Economic and Social Committee and the Committee of the Regions - New Skills for New Jobs - Anticipating and matching labour market and skills needs.

Dyr T., Ziółkowska K. (2016). The economic infrastructure as the factor of creating the microregions' economic potential, „Central European Review of Economics \& Finance", Vol. 15, No. 5.

Dyr T., Ziółkowska, K. (2014). Economic infrastructure as factor of the region's competitiveness, „Central European Review of Economics \& Finance”, Vol. 6, No. 3.

DzU 2009, nr 4, poz. 17: Rozporządzenie Ministra Edukacji Narodowej z dnia 23 grudnia 2008 r. w sprawie podstawy programowej wychowania przedszkolnego oraz kształcenia ogólnego w poszczególnych typach szkół.

Feltynowski M., Nowakowska A. (2009). Metoda oceny potencjału innowacyjnego regionów, [in:] Nowakowska A. (ed.), Zdolności innowacyjne polskich regionów, Wydawnictwo Uniwersytetu Łódzkiego, Łódź.

Figurska I, Wiśniewski E. (2009). Konkurencyjność regionów w gospodarce opartej na wiedzy, „Zeszyty Naukowe Małopolskiej Wyższej Szkoły Ekonomicznej w Tarnowie", No. 2(13), t. 1.

Hellwig Z. (1968). Zastosowanie metody taksonomicznej do typologicznego podziału krajów ze względu na poziom ich rozwoju i strukturę wykwalifikowanych kadr, „Przegląd Statystyczny”, nr 4.

Makulska D. (2012). Kluczowe czynniki rozwoju w gospodarce opartej na wiedzy, „Prace i Materiały Instytutu Rozwoju Gospodarczego SGH”, nr 88.

Maráková V., Dyr T., Wolak-Tuzimek A. (2016). Factors of tourism's competitiveness in the European Union countries, „E\&M Economics and Management" No. 3.

Niedzielski P. (2013). Kreatywność i procesy innowacyjne na rysunku usług transportowych, Polskie Towarzystwo Ekonomiczne, Szczecin.

Niedzielski P., Rychlik K. (2006). Innowacje i kreatywność, Wydawnictwo Uniwersytetu Szczecińskiego, Szczecin.

Pająk A., Orzeł A. (2016). The economic effects of the implementation of the Operational Programme Development of Eastern Polish 2007-2013, „Central European Review of Economics \& Finance", Vol. 15, No. 5. 
Schumpeter J. (1960). Teoria rozwoju gospodarczego, PWN, Warszawa.

Skonieczny J., Świda A. (2008). Innowacyjność jako czynnik wzrostu konkurencyjności regionu, [in:] Noga M., Stawicka M. (eds.), Problemy gospodarki światowej, „Prace Naukowe Akademii Ekonomicznej we Wrocławiu”, z. 1191. Skrzypek E. (2008). Miejsce i znaczenie wiedzy w zrównoważonym rozwoju, [in:] Żuchowski J. (ed.) Filozofia TQM w zrównoważonym rozwoju, Wydawnictwo Politechniki Radomskiej, Radom.

Skrzypek E. (2009). Kapitał intelektualny w organizacji, Wydawnictwo Uniwersytetu Marii Curie-Skłodowskiej, Lublin. 